\title{
Development of an optimized array wheel probe for inspection of fibre glass composites
}

\author{
Opracowanie optymalnej głowicy oponowej \\ Phased Array do badań kompozytów \\ z włóknem szklanym
}

\section{Abstract}

With growing maturity in the Wind power industry has come the need to maximise the efficiency and reliability of turbine equipment. One key aspect of this is weight reduction, both to reduce manufacturing cost and to reduce loading on gearboxes, bearings and associated equipment.

However to reduce the weight of the blades we must ensure that they perform as designed. Non-destructive testing is a key element of this. Most Turbine blade structures contain a large amount of glass-fibre, which is a notoriously difficult material to inspect with ultrasonic techniques.

Sonatest have developed a variant of their Array wheel probe, optimised for inspection of Difficult composite materials and employing 'lower than normal' inspection frequencies. This paper discusses the design optimisations, and details the results obtained.

\section{Streszczenie}

Wraz z rosnącym zaawansowaniem energetyki wiatrowej pojawiła się potrzeba maksymalizacji sprawności i pewności elementów turbiny wiatrowej. Jednym z ważniejszych zadań była redukcja masy, kosztów wytwarzania i ciężaru przekładni, łożysk oraz innego wyposażenia.

Redukcja masy łopat wirnika musi być związana z pewnością bezaawaryjnego działania zgodnie z założeniami projektowymi. Badania nieniszczące (NDT) są jednym z narzędzi kontrolnych. Większość konstrukcji łopat wirników zawiera duże ilości włókna szklanego, które jest znane jako bardzo trudny materiał do badań technikami ultradźwiękowymi.

Sonatest udoskonalił wariant oponowej głowicy Phased Array, optymalizując ją do badań tych trudnych kompozytów przez zastosowanie częstotliwości niższej niż normalnie. Ten artykuł pokazuje dokonaną optymalizację oraz osiągnięte rezultaty.

\section{Introduction - the problem}

As the political and economic case for wind Power grows stronger the demand is for higher powered and more cost-effective turbine systems. One obvious aspect of this is that the turbine blades get longer. When Sonatest was first involved in Wind systems (around 2004) $3 \mathrm{MW}$ generators with $40 \mathrm{~m}$ blades were state of the art, now we have systems of more than twice

Joe Buckley - Sonatest Ltd. this power with $75 \mathrm{~m}$ blades being installed (Siemens Wind Energy). It seems inevitable that we will approach $100 \mathrm{~m}$ blade length before too many more years have passed.

However as blades get longer there are serious engineering challenges. These huge structures increase in weight almost exponentially as the length increases - they need to be sturdier to support their own weight, so for any given construction technology we reach a point of diminishing returns.

As with all engineering, reducing weight eliminates the possibility to over-design and it becomes essential that structures perform as expected. Effective NDT 


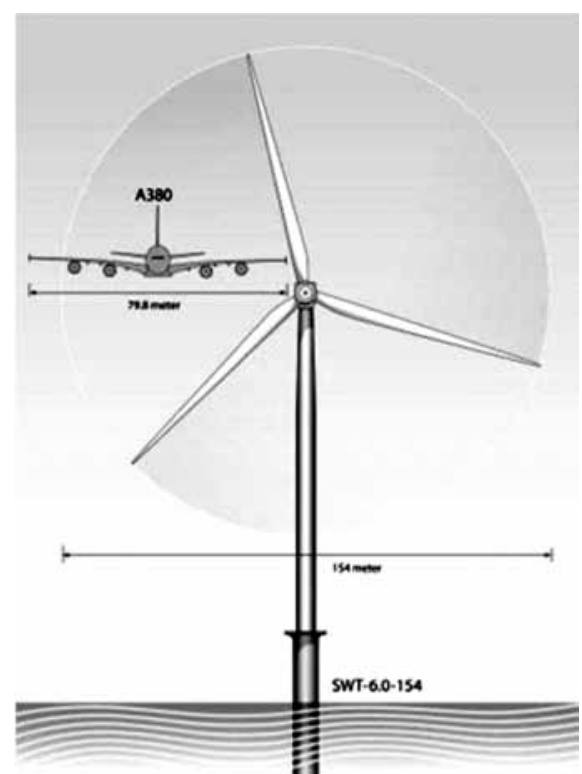

Fig. 1. Modern wind turbine, with $A 380$ shown for scale Rys. 1. Nowoczesna siłownia wiatrowa $z$ samolotem Airbus A380 w odpowiedniej skali

is becoming more and more important, especially as modern blade designs rely on high-strength bonds

However as we know composite materials present many Inspection challenges (Buckley, 2006), especially glass fibre, where ultrasonic inspection becomes difficult due to the acoustic mismatch between the matrix and reinforcement materials.

The sheer size of the structures involved means that any inspection technique must be quick and, as far as possible, provide unambiguous results. Minimising the cost of inspection is very important.

\section{Sonatest Wheel Probes - Back ground}

Sonatest has been involved in the development of wheel probes using array technology since NDT Solutions, which became part of Sonatest, became involved in an Airbus-supported project around the beginning of the century. This project, which used an innovative polymer technology developed at Bristol University, resulted in a sensor design that incorporated a $5 \mathrm{MHz}$ 64 element array, inside a water-filled wheel. The tyre is made using a special polymer material, which is acoustically matched to water. This gives both good near surface resolution, comparable to an immersion system, and the ability to scan a fairly thick material without interference from internal echoes.

This approach has been very successful, providing a tool (Brotherhood, Drinkwater, \& Freemantle, 2003) which is easy to handle, and is capable of giving good ultrasonic results while being scanned at fairly high speed over surfaces of moderate roughness, where it is very difficult to scan consistently using a conventional delay line probe.
The basic design has been developed and has evolved in several stages, Today we have a range of probes available, used primarily for two applications: Inspection of high-performance (mainly aerospace) composites and corrosion inspection, mainly in pipework for the petrochemical industry.

Around 2004 an automated system using a low frequency large wheel for Wind Turbine Blade inspection was developed. That system was mechanically scanned, and was too large for manual use. With increasing demand from this sector, a project was launched to resurrect and develop this idea in order to create a probe design which was more suitable for general use.

\section{Custom development}

Key priorities for the new design:

1. Ergonomic design suitable for use by hand,

2. Acceptable pressure required in use,

3. Acceptable weight (target $5 \mathrm{~kg}$ ),

4. Sufficient internal water path to allow use on Composites up to $70 \mathrm{~mm}$ thick,

5. Easy to build, use and service.

Two initial design concepts were considered:

One was similar to our existing 'radius wheel probe' using an aluminium frame. The second developed this further using a frame mostly carbon fibre and nylon SLS parts. It was felt that the carbon fibre construction conveyed significant weight and appearance benefits (avoiding the need for anodised parts) and, as a colleague put it. "We make equipment to test composite materials - We should understand them well enough to use them".

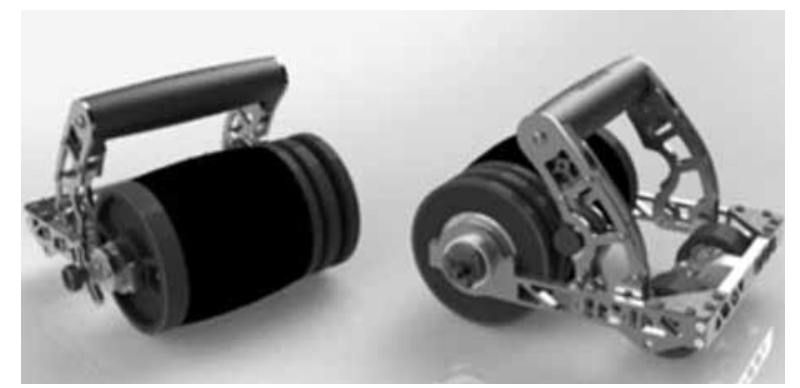

Fig. 2. Aluminium developed concept

Rys. 2. Rozwiązanie z ramą aluminiową

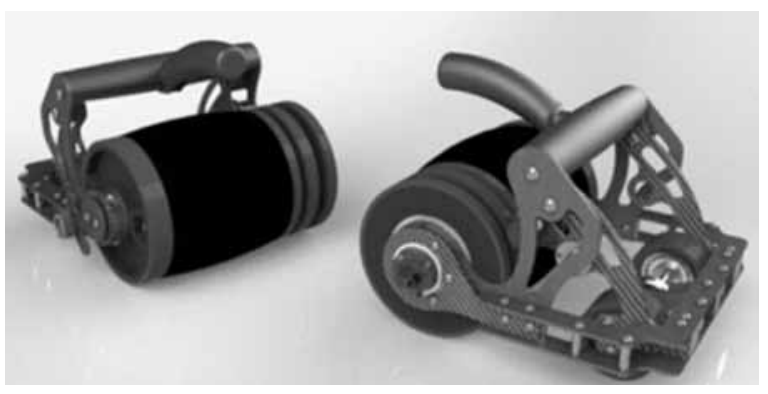

Fig. 3. Composite developed concept

Rys. 3. Rozwiązanie z ramą z włókna węglowego 


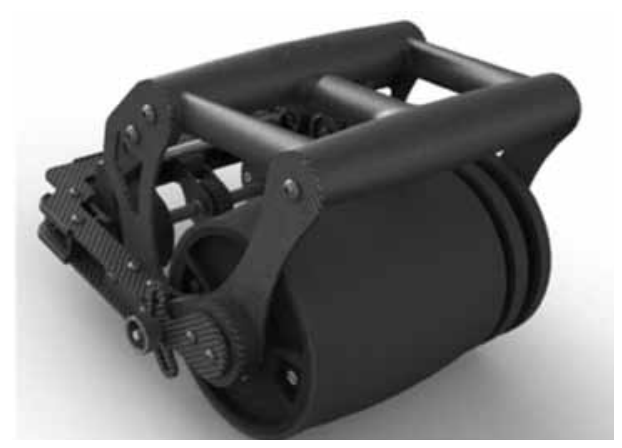

Fig. 4. Rendered CAD design

Rys. 4. Projekt opracowany w CAD

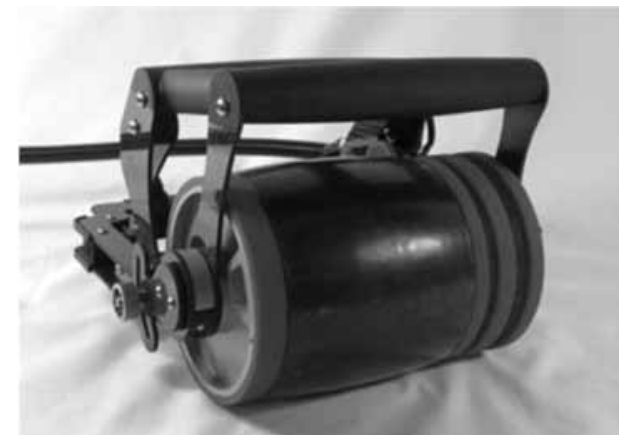

Fig. 5. Photograph of prototype

Rys. 5. Zdjęcie prototypu

A full design was approved based on the composite concept. Needless to say there were many detail changes along the way. The 'final' design that emerged looked like this:

\section{Experimental validation}

The probe was tested on a wide variety of samples, mostly glass fibre and glass carbon combinations. It was apparent that both $1 \mathrm{MHz}$ and $500 \mathrm{KHz}$ frequencies were needed to permit optimisation of resolution on thinner samples, while giving good penetration of thicker materials.

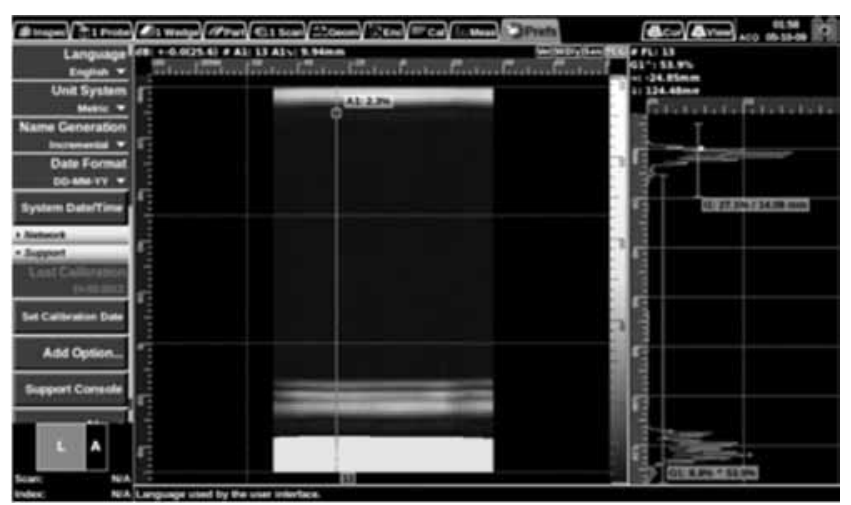

Fig. 6. Time to first tyre echo

Rys. 6. Czas do pierwszego echa opony
A lot of work was carried out to maximise the water path length. The current design (which could potentially be optimised further) gives a time until the second reflection equivalent to approximately $110 \mathrm{~mm}$ in epoxy matrix Glass fibre (assumed velocity $3000 \mathrm{~ms}^{-1}$ ) as shown in Fig. 6.

\section{Results on various GFRP samples at $500 \mathrm{kHz}$ and $1 \mathrm{MHz}$}

Gain and TCG adjusted as required.

As can be seen the $1 \mathrm{MHz}$ array gives slightly better resolution, but at the cost of an increased material noise, and the $41 \div 47 \mathrm{~mm}$ thickness in GFRP represents pretty much the maximum thickness that can be tested at $1 \mathrm{MHz}$. Given that these samples were made to a higher quality level (i.e. fully saturated fibre) than is necessarily to be expected in 'good' material. It seems that $0.5 \mathrm{MHz}$ is probably the most sensible frequency to use in practice.

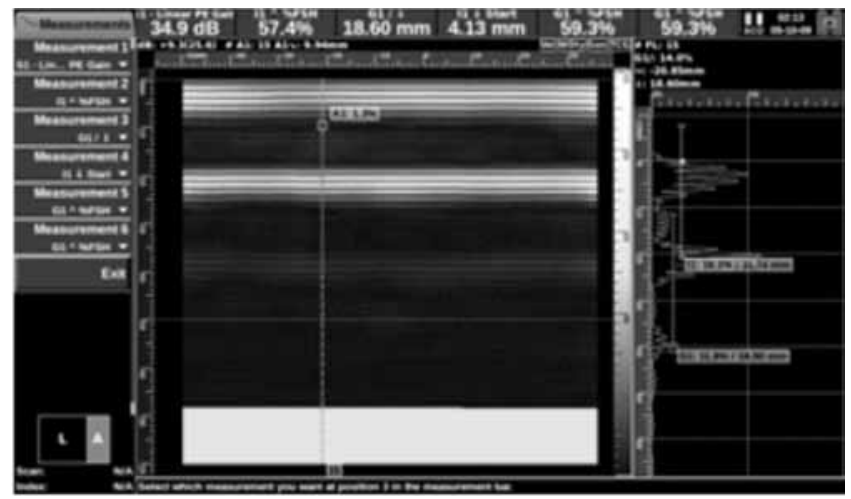

Fig. 7. WEWP, $500 \mathrm{kHz}, 18.7 \mathrm{~mm}$ GFRP

Rys. 7. WEWP, $500 \mathrm{kHz}, 18.7 \mathrm{~mm}$ GFRP

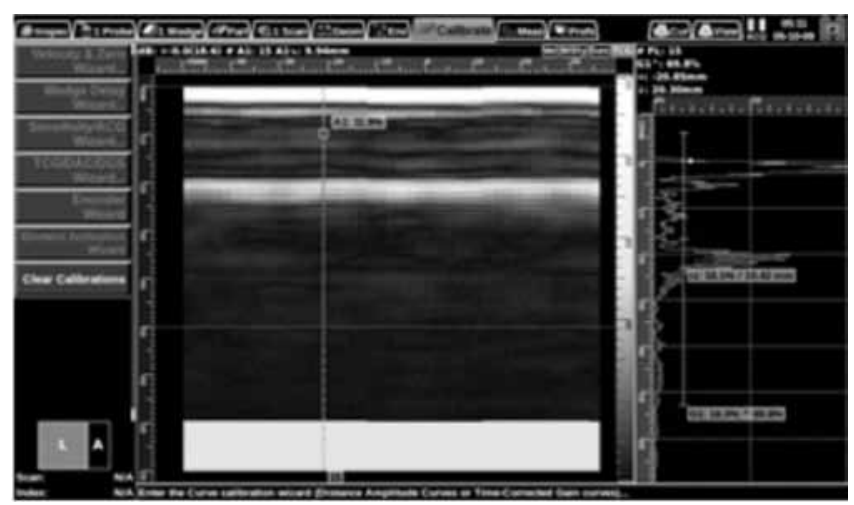

Fig. 8. WEWP, $1 \mathrm{MHz}, 18.7 \mathrm{~mm}$ GFRP

Rys. 8. WEWP, $1 \mathrm{MHz}, 18,7 \mathrm{~mm}$ GFRP 


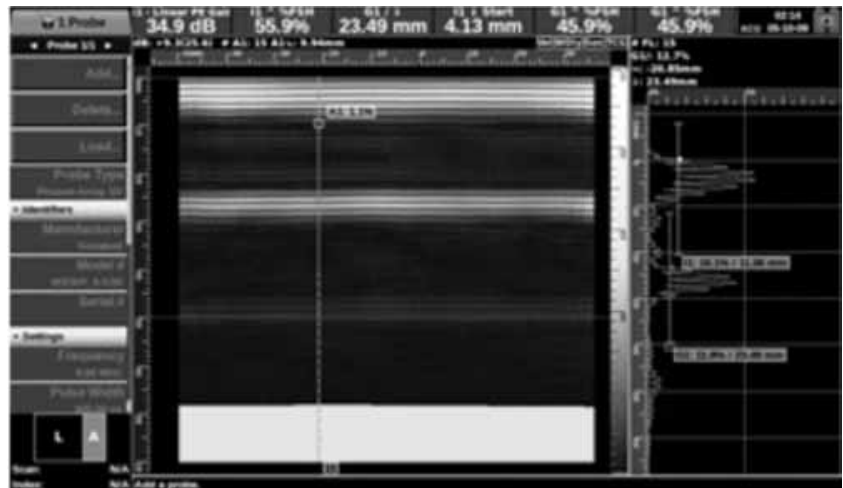

Fig. 9. WEWP, $500 \mathrm{kHz}, 24 \mathrm{~mm}$ GFRP Rys. 9. WEWP, $500 \mathrm{kHz}, 24 \mathrm{~mm}$ GFRP

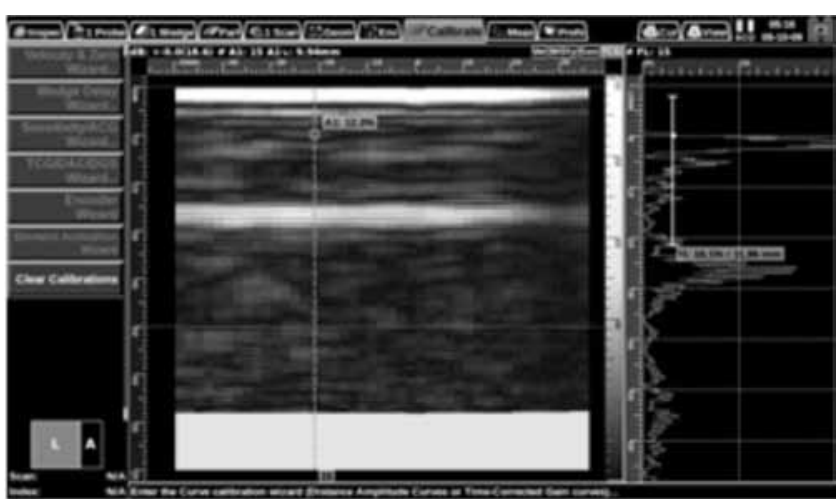

Fig. 10. WEWP, $1 \mathrm{MHz}, 24 \mathrm{~mm}$ GFRP

Rys. 10. WEWP, $1 \mathrm{MHz}, 24 \mathrm{~mm}$ GFRP

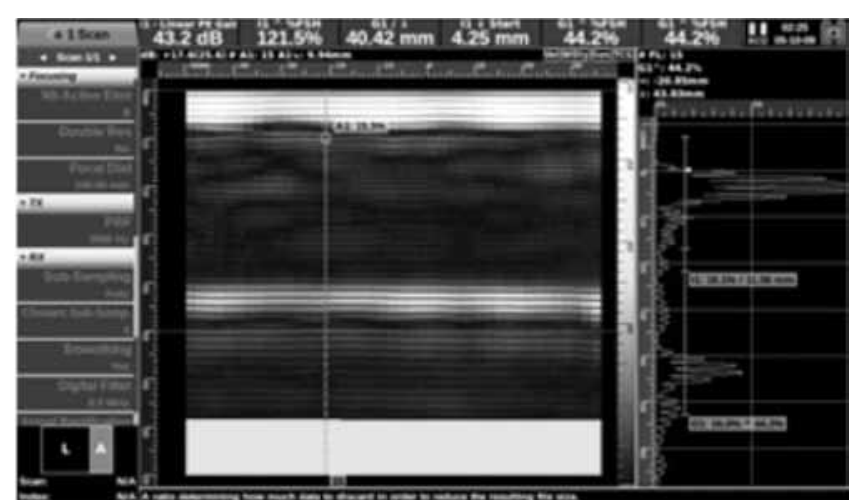

Fig. 11. WEWP, $500 \mathrm{kHz}, 41 \mathrm{~mm}$ GFRP Rys. 11. WEWP, $500 \mathrm{kHz}, 41 \mathrm{~mm}$ GFRP

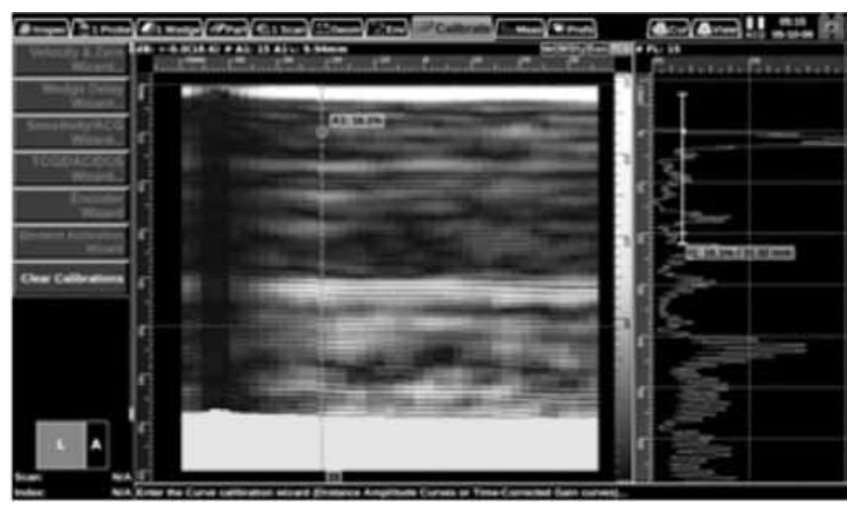

Fig. 12. WEWP, $1 \mathrm{MHz}, 41 \mathrm{~mm}$ GFRP

Rys. 12. WEWP, $1 \mathrm{MHz}, 41 \mathrm{~mm}$ GFRP

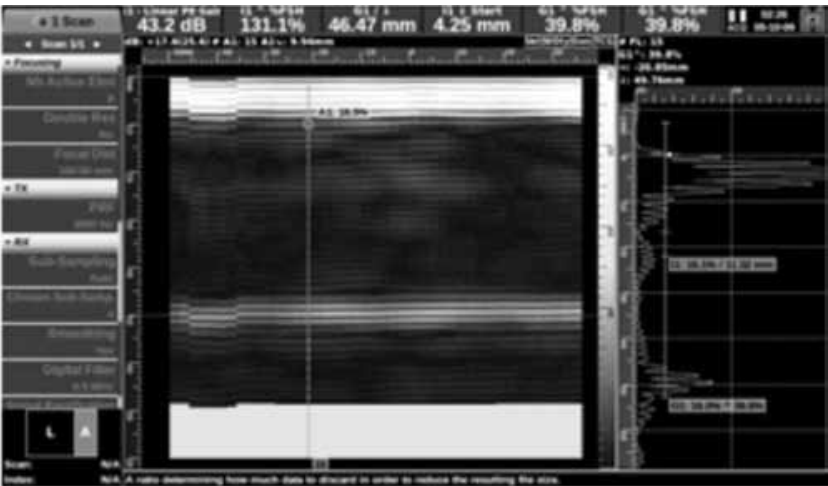

Fig. 13. WEWP, $500 \mathrm{kHz}, 47 \mathrm{~mm}$ GFRP Rys. 13. WEWP, $500 \mathrm{kHz}, 47 \mathrm{~mm}$ GFRP

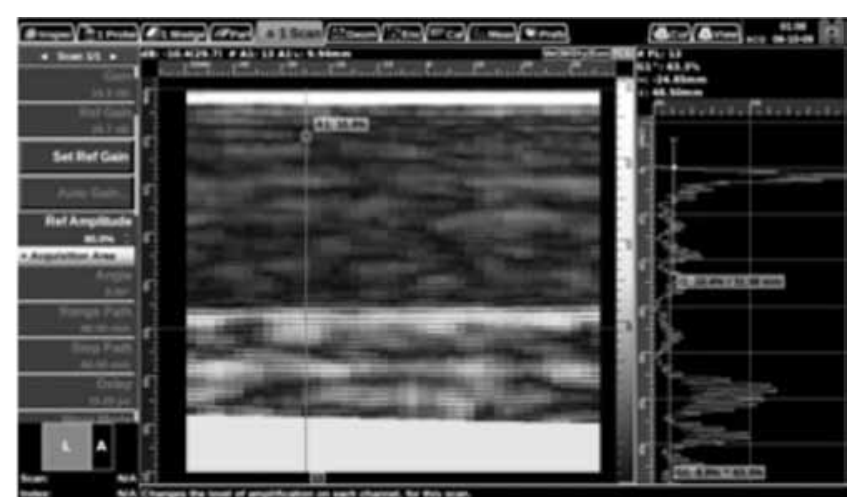

Fig. 14. WEWP, $1 \mathrm{MHz}, 47 \mathrm{~mm}$ GFRP

Rys. 14. WEWP, $1 \mathrm{MHz}, 47 \mathrm{~mm}$ GFRP

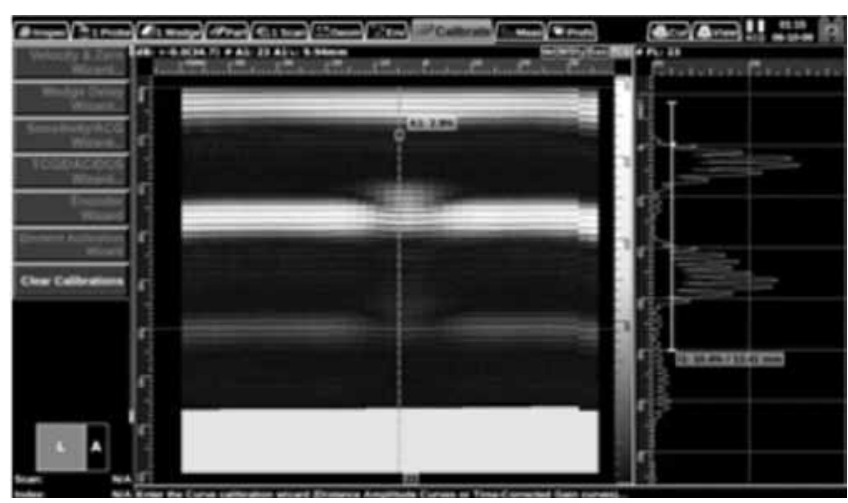

Fig. 15. WEWP, $500 \mathrm{kHz}, 8 \mathrm{~mm} \mathrm{FBH}, 4 \mathrm{~mm}$ from back wall in 20 $\mathrm{mm}$ acrylic

Rys. 15. WEWP, 500 kHz, 8 mm FBH, 4 mm od tylnej ścianki w 20 $\mathrm{mm}$ acrylic

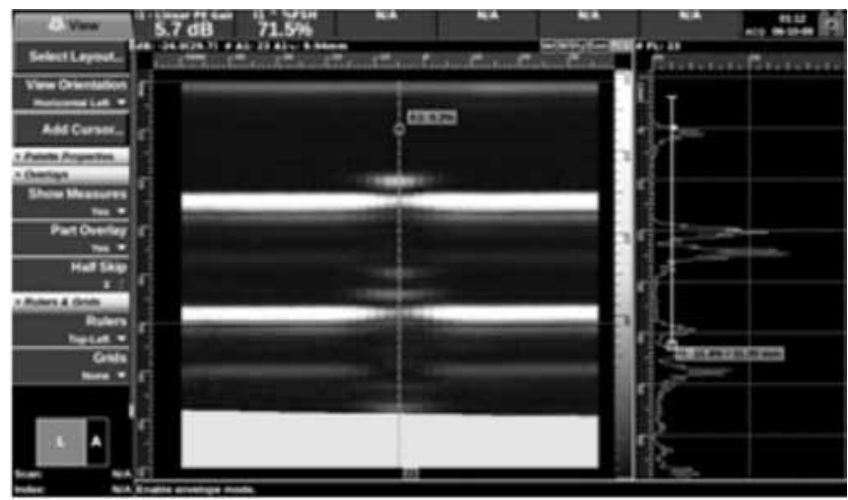

Fig. 16. WEWP, $1 \mathrm{MHz}, 8 \mathrm{~mm}$ FBH, $4 \mathrm{~mm}$ from back wall in $20 \mathrm{~mm}$ acrylic

Rys. 16. WEWP, $1 \mathrm{MHz}, 8$ mm FBH, 4 mm od tylnej ścianki w 20 $\mathrm{mm}$ acrylic 


\section{Experimental work on test panel}

A large GFRP test panel was inspected using the 500 $\mathrm{kHz}$. Wheel probe attached to a 2D scanning frame.

This panel had a number of inserts at various depths, and also a resin-poor region in the centre - This obscured some of the defects, so a scan from both sides would be ideal.

The images below show back wall amplitude and depth $\mathrm{C}$ - scans of this sample. Note that near surface defects fall outside the gate and show as dark.

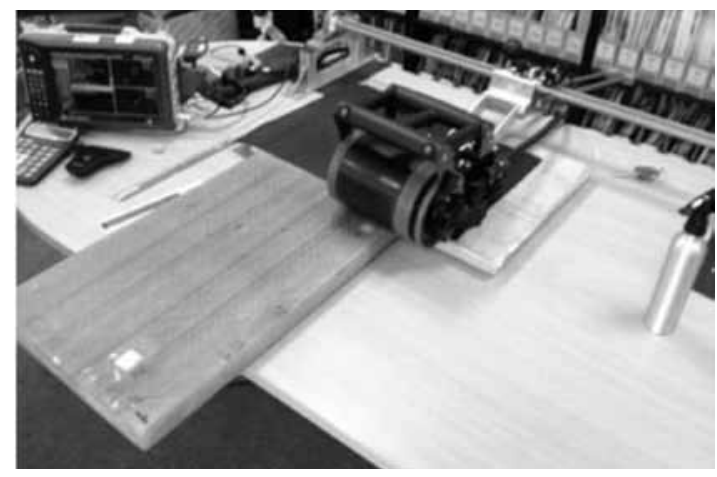

Fig. 17. Experimental setup for 2D scan

Rys. 17. Eksperymentalne ustawienie dla skanu 2D

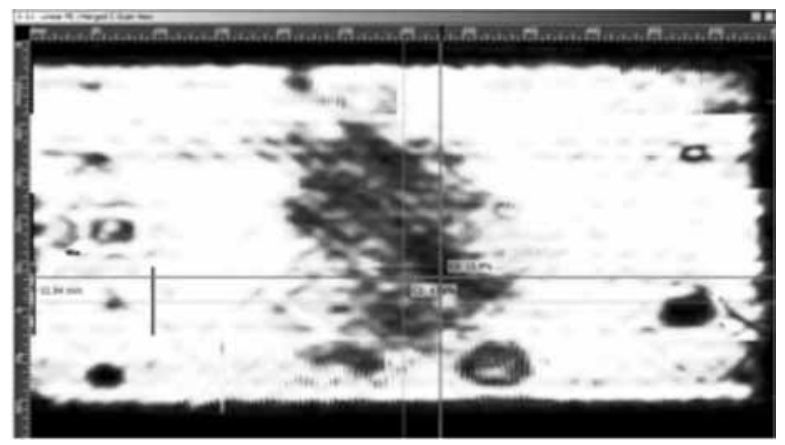

Fig. 18. Back-wall amplitude

Rys. 18. Amplituda tzw. dna

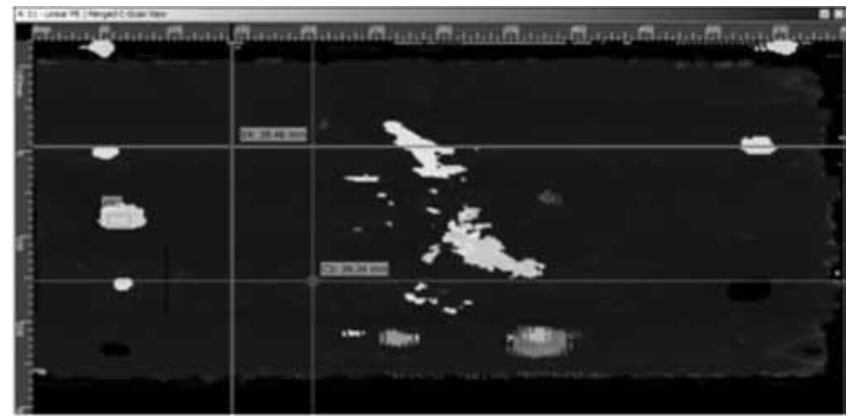

Fig. 19. Depth to largest echo in gate

Rys. 19. Głębokość dla największego echa w bramce

\section{Conclusions}

The 'Wind Energy Wheel Probe' design is now ready for market and shows promise in a lot of key areas. We look forward to discussing its applications in future.

\section{Field Trials}

Field trials were carried out with a number of potential customers.
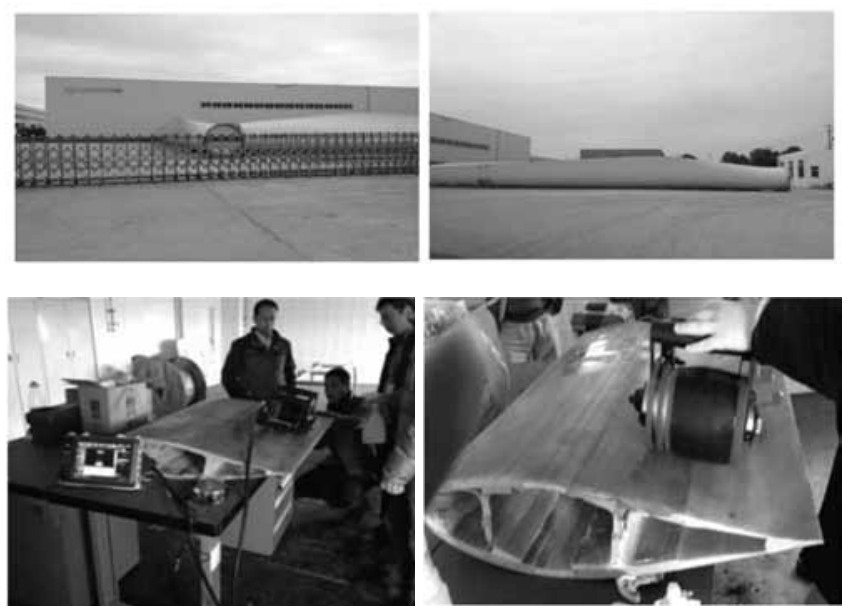

\section{Design Refinement}

Following the field trials a number of design changes were made, in particular:

- The handle was redesigned for improved comfort, and to suit people with larger hands!

- The trail wheel adjustment was simplified.

- Control buttons were added.

- The tyre edge sealing was modified.

As well as a number of other changes which were carried out to ease manufacturing and service.

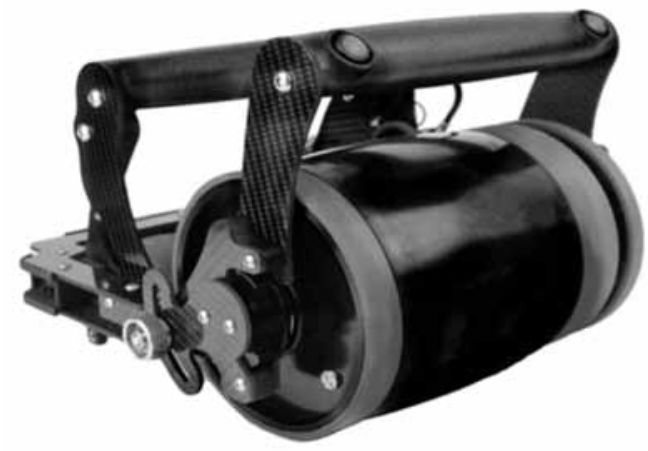

\section{References}

[1 ]Brotherhood, C. J., Drinkwater, B. W., \& Freemantle, R. J. (2003). An ultrasonic wheel-array sensor and its application to aerospace structures. Insight, 45 (11), 729-734.

[2] Buckley, J. M. - (2006). A comparison of Techniques for UItrasonic Inspection of Composite Materials.

[3] 12th Asia-Pacific Conference of NDT. Auckland, NZ.

[4] Siemens Wind Energy. (n.d.). Siemens 6.0 MW Offshore Wind Turbine. Retrieved August 5th, 2013, from http://www. swe.siemens.com/spain/web/es/energy/energias_renovables /eolica /Documents/6MW_direct_drive_offshore_ wind_turbine.pdf 